\title{
The Margaret Wrong Medal 1954
}

DURING the last four years a silver medal and a money prize have been offered for original writing by Africans in European languages (French, English, and Portuguese) and Afrikaans. There has been a steady demand for the inclusion of African languages also, and to meet this demand and also to simplify the complicated problem of fair adjudication, two awards are in future to be made: a money prize, to be known as the MARGARET WRONG PRIZE, is to be offered each year to Africans from all parts of Africa south of the Sahara, for original manuscripts in specified European languages-notice of this prize for 1954 was published in the January number of Africa. THE MARGARET wRONG MEDAL will in future be offered in a different area of Africa each year for a published book in an African language; the regulations for 1994 are as follows:

I. The MARGARET WRONG MEDAL is offered in 1954 for a published work of outstanding merit by an African whose home is in Belgian Congo (including Ruanda-Urundi), Southern Sudan, Uganda, Kenya, Tanganyika, or Zanzibar.

2. Only original work written in an African language or in Arabic, and published between I January I95 I and 3 I December 1954, will be considered.

3. Except for entries comprising collections of original verse, books of less than 25,000 words will not be considered.

4. No author may submit more than one book, two copies of which should be delivered before 28 February i 95 s, to:

The Director, East African Literature Bureau,

P.O. Box 2022, Nairobi,

Kenya. (For entries from Uganda, Kenya, Tanganyika, Zanzibar).

The Language and Publications Office, Ministry of Education, Juba, S. Sudan.

(For entries from Southern Sudan).

M. le Chef du Bureau d'Information pour Indigènes,

B.P. 3906 à Kalina, Léopoldville.

(For entries from Belgian Congo).

9. Entries should be clearly marked MARGARET WRONG MEDAI.

Note: After examination by judges competent in the language in which each book is written, any book which is recommended will be forwarded to London, where the award will be made. The decision of the judges will be final.

NO AWARD WILL BE MADE UNLESS A WORK OF OUTSTANDING MERIT IS PRESENTED. 